\title{
Effect of "Selebgram" on Interest of Buying Generation Z Users of Instagram Based on Gender Perspective
}

\author{
Mutia $\mathrm{Arda}^{1}$, Dewi Andriany ${ }^{2}$ \\ \{mutiaarda@umsu.ac.id $\left.{ }^{1}\right\}$ \\ University of Muhammadiyah Sumatera Utara, Medan, Indonesia
}

\begin{abstract}
Generation $\mathrm{Z}$ is a group of people who are most dominant using Instagram applications that were born in the range of 1995-2010. Instagram is a social media that is used to publish photos and videos to friends and Instagram can also be used for business facilities. If the business being run is a business that targets teenagers, it is suitable to use Instagram as a promotional medium. Consumer interest in owning and buying products is influenced by the encouragement from the consumers to own and buy products. Men's buying paths are shorter and more straight while women are like spirals, often returning to the previous step to gather new information before moving forward to find the right choice. The number of samples in this study were 100 people consisting of 50 women and men respectively. The analysis technique used in this study is simple linear regression. Based on the results of the study concluded that the use of celebrities for products sold on Instagram social media greatly influences its users, especially the $\mathrm{Z}$ generation who are women who believe in selegram in influencing their buying interest compared to the $\mathrm{z}$ generation of men.
\end{abstract}

Keywords: Selebgram, Buying Interest, Instagram.

\section{Introduction}

Generation $\mathrm{z}$ is currently a topic that is quite warm among the people of Indonesia. Generation $\mathrm{Z}$ is a group of people born after the millennials, that is, people born in the range of 1995-2010. High technology is inherent in their blood, they have grown in uncertain and complex environments that determine their views about work, study and the world. They have different expectations in their workplace, career-oriented, an ambitious generation of professionals, possessing high-level technical skills and language knowledge.

The new social media forms consist of many types and categories including search engines (Yahoo, Google, Ask), social networks (Facebook, Twitter, LinkedIn, Tumblr, MySpace, Skype), Share photos (Instagram, flickr, foursquare), share videos (YouTube, Vine, Instagram), email (Gmail, Hotmail, Yahoo), instant messages (Whatsapp, Line), share magazines (Flipboard) (Lattimore, Dan, O.Baskin, S.T. Heiman, \& E. L. Toth,2009).

One of the most widely used social media for internet generation or $\mathrm{Z}$ generation is Instagram. Instagram is a social media that is used to publish photos and videos to friends and Instagram can also be used for business facilities. If the business being run is a business that targets teenagers, it is suitable to use Instagram as a promotional medium. The number of 
online stores that appear on Instagram makes a new phenomenon among the public. Instagram is used as a medium to promote and sell products.

Instagram became a new media promotion that proved its interest in buying came from teenagers who saw celebrity endorsers (selebgram) who use the product to look more interesting. The use of celebrity is different because typical new media instagram allows anyone can be a celebrity supporter, not just an artist famous as in various conventional media (Totoatmojo,2015).

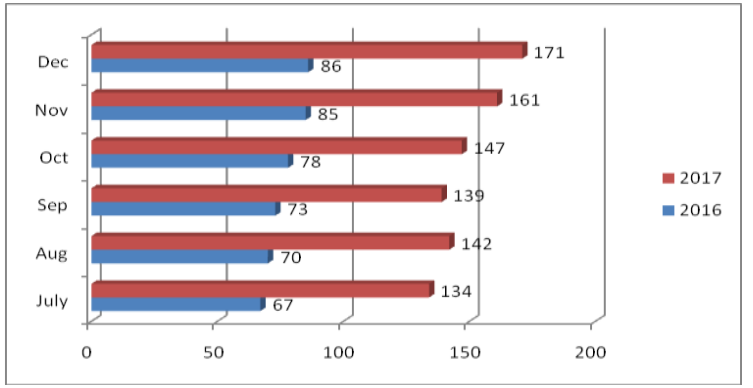

Figure 1. Volume of Instagram Usage in the World July-December Period in 2016 and 2017

Based on data published by emarketer.com in January 2018 it is known that the number of Instagram users in the world has almost doubled. By the end of 2016 it was known that the number of active users of Instagram was 86,000,000 users, while at the end of 2017 it was $171,000,000$ Instagram users. Based on information published by katadata.co.id it is known that Indonesia is included in 10 countries with the largest number of active Instagram users.

At this time the term endorse appears to be a trend for Instagram users. Endorse is a way to promote the products of an online store by working with people who have lots of followers on Instagram (selebgram). These people are among artists, politicians, or ordinary people who have a lot of followers. selebgram is often also referred to as direct source (direct source) which is a speaker who delivers a message and or demonstrates a product or service (Belch,2009).

Several existing studies, including (Pratiwi,2016) said three important frameworks that lead to consumer attitudes, namely trustworthiness, attractiveness, and expertise possessed by celebrities towards the buying interest of Instagram social media users of Alauddin State Islamic University students in Makassar. (Sugiarto,2012) shows that the influence of Celebrity Endorser, namely Visibility, Credibility, Attraction, and Power, influence the buying interest of consumers of Mie Sedap products.

Consumer interest in owning and buying products is influenced by the encouragement from the consumers to own and buy products. Encouragement from within the consumer to have a product is a response to stimuli both from the outside and from within the consumer. Consumers have an interest in buying the product they want. (Kotler and Armstrong,2009) defines buying interest as a behavior that arises in response to an object that shows the customer's desire to make a purchase.

Men's buying paths are shorter and more straight while women like spirals, often return to the previous step to gather new information before moving forward to find the right choice, in (Kotler, Kartajaya, and Setiawan,2016).

Through various descriptions above, the research will be carried out with the title "The Influential Effects on Interest in Buying Generations of Z Social Media Users Instagram in Medan Based on a Gender Perspective". 


\section{Literature Review}

\subsection{Generation Z}

Generation $\mathrm{Z}$ is the generation of people who were born close to 2000 (1995-2010). This generation is also very comfortable and familiar with the virtual world (digital) because they have been confronted with technology since they were born, such as the internet, smartphones, video streaming, and social media. Their consumption of the technology is very large. One of them is the tendency of internet use. Generation $\mathrm{Z}$ also has a trend to use sophisticated equipment without worrying about its effects (Wood,2013).

\subsection{Selebgram}

The definition of a celebrity endorser is an individual who enjoys public recognition and the individual uses this recognition on behalf of consumer goods by appearing with him in an advertisement (McCracken, G, 1989). Defenition of the celebrity itself is a public figure or someone known to the public, such as athletes, film players, politicians and others who are well-known and often appear in the media and or become a model of advertising a product (Shimp, 2007). Meanwhile, celebrity endorsers on Instagram or commonly known as selebgram is a term for those who are trusted to bring products sold online through an Instagram account. They are not always someone famous through the entertainment world, although there are some top artists who want to accept an offer to become an endorser. Stated one alternative to evaluating celebrities in advertising using the VisCAP model. The VisCAP method consists of visibility, credibility, attraction and power (Royan,2004). Visibility is how well known or recognized by people or characters in front of the public (Hughes, $\mathrm{G} \&$ fill, chris,2006). Credibility is the extent to which the recipient sees the source or someone public figure has relevant knowledge, skills, or experience and trusts the source to provide objective and objective information (Goldsmith, R., Lafferty, B., Newell, S,2000). Attractiveness has two components, namely preference for the source and similarity of perceptions of the source with the target audience (Erdogan, B.Z,1999). Power is the ability of the source to embed compliance with the part of the target audience (Erdogan, B.Z,1999).

\subsection{Buy Interest}

Consumer buying interest is something that arises after receiving stimulation from the product he sees, from there arises an interest in trying the product until eventually the desire to buy arises to be able to own it (Kotler and Keller, 2009). Buying interest is an impulse that arises in a person to buy goods or services in order to fulfill their needs (Mc.Carthy, 2009). There are several indicators contained in buying interest, among others: 1) Interest that shows concentration and feeling of pleasure, 2) Desire is indicated by the urge to have, 3) Confidence (conviction) is indicated by the feeling of individual confidence in the quality, effectiveness and benefits of the product to be purchased (Natalia,2008). The evaluation phase of purchasing decisions directs consumers to form preferences among brands among various choices (Tyagi, C.L \& kumar, arun, 2004). Halim and Hameed explain buying interest as the number of customers who have the desire to buy products in the future and make repeat purchases and contact again for certain products (Fandos, C., Flavian, C., 2006). 


\section{Research Methods}

\subsection{Population and Sample}

The population in this study is generation $\mathrm{z}$ or also known as the internet generation in Indonesia which is an active Instagram user aged 18-23 years whose population is unknown. This population selection is also based on a study which states that Instagram users in Indonesia 59\% are young people aged 18-24 years who are educated and established, (www.cnn.com).

Specific consideration criteria for the sample in this study are respondents who meet the following criteria: (1) Respondents aged 18-23 years (2) Respondents are active Instagram users. (3) Respondents follow (follow) at least one program on an Instagram account, (4) Respondents have purchased products online via Instagram at least once. The number of samples in this study were 100 people consisting of 50 women and men.

\subsection{Validity and Reliability Test}

Based on the results of statistical analysis with the SPSS 22 for Windows program, the results of the validity and reliability tests were obtained as follows:

Table 1: Validity and Reliability Test Results.

\begin{tabular}{|c|c|c|c|c|}
\hline No & $\begin{array}{c}\text { Corrected } \\
\text { Item-Total } \\
\text { Correlation }\end{array}$ & $\begin{array}{c}\text { Status } \\
\text { Validity }\end{array}$ & $\begin{array}{c}\text { Cronbach's } \\
\text { Alpha }\end{array}$ & $\begin{array}{c}\text { Status } \\
\text { Reliability }\end{array}$ \\
\hline 1 &, 970 & Valid &, 935 & Reliable \\
\hline 2 &, 907 & Valid &, 954 & Reliable \\
\hline 3 &, 912 & Valid &, 952 & Reliable \\
\hline 4 &, 857 & Valid &, 968 & Reliable \\
\hline 5 &, 925 & Valid &, 911 & Reliable \\
\hline 6 &, 945 & Valid &, 897 & Reliable \\
\hline 7 &, 834 & Valid &, 982 & Reliable \\
\hline
\end{tabular}

Based on the results of data processing, all instrument items are declared valid because of the corrected item-total correlation value> $\mathrm{r}$ table value (0.361). All instrument items are declared feasible to use, this can be evidenced from the Cronbach's alpha value of all instruments that are greater than the constant value of 0.6.

\subsection{Simple Regression Analysis}

This analysis is used to find out how big the influence of bound variable. Regression method is formulated as follows:

$$
\mathrm{Y}=\mathrm{a}+\mathrm{b}_{1} \mathrm{X}_{1}+\mathrm{e}
$$

$$
\begin{array}{ll}
\mathrm{Y} & : \text { Buy Interest } \\
\mathrm{a} & : \text { constants } \\
\mathrm{b}_{1} & : \text { multiple regression coefficient }
\end{array}
$$




\section{$\mathrm{X}_{1} \quad$ : Selebgram as Endorser \\ e : standart error.}

\section{Result and Discussion}

The $\mathrm{t}$ test is used to determine and search for the influence of independent variables individually affecting the dependent variable. Hypothesis testing is done by comparing the tcount value with the t-table value with the decision criterion is if $t$-count $<\mathrm{t}$-table $\mathrm{H}_{0}$ is accepted or $\mathrm{H}_{1}$ is rejected, and if $\mathrm{t}$-count $>\mathrm{t}$-table $\mathrm{H}_{0}$ is rejected or $\mathrm{H} 1$ is accepted.

Table 2: Test-t (Women)

\begin{tabular}{|c|c|c|c|c|}
\hline \multirow{2}{*}{ Model } & \multicolumn{2}{|c|}{$\begin{array}{c}\text { Unstandardized } \\
\text { Coefficients }\end{array}$} & \multirow{2}{*}{$\mathrm{t}$} & \multirow{2}{*}{ Sig } \\
\cline { 2 - 3 } & $\mathrm{b}$ & Std. Error & & \\
\hline (Constant) & $-3,537$ & 3,021 & $-1,171$ &, 247 \\
\hline Selebgram &, 922 &, 170 & 5,413 &, 000 \\
\hline
\end{tabular}

The value of t-count $>\mathrm{t}$-table is $5.413>1.6759$ and the significant value for the celebrity is $0.000<$ alpha 0.05 , the coefficient value is 0.922 so the celebrity variable has a positive and significant effect on the buying interest of generation $\mathrm{Z}$ which is female, instagram social media users thus the hypothesis is accepted.

The female $\mathrm{Z}$ generation who is now the most influential generation in the world economic and technological movement tends to believe in the merchandise of small-scale followers rather than those who have millions of followers. According to Bodker, this is closely related to the attitude of the generation which is indeed more individual than the previous generation.

First, fewer Instagram users who follow generally have higher involvement with their followers. The percentage of thumbs 'likes' and comments is higher than the celebrities with millions of followers.

That's because the exclusive nature of the celebrities is small, unlike celebrities with millions of followers who tend to be minimal or even unable to communicate interactively. This has an effect on the second point: competitive prices.

Advertise on a small number of participants with the fact that they have a lower advertising price offer than those who already have names. That is certainly enticing for example for small companies, or new startup businesses, who want to promote their sales. After all, the expensive costs of advertising on a group of millions of followers may not necessarily be proportional to the income. Promotional budgets can be saved more easily, for example, to advertise on a number of celebrities who follow a little rather than in one program of millions of followers.

The third point relates to the Generation $\mathrm{Z}$ individual attitude. They realize that celebrity life cannot be cheap. So the products at affordable prices that they endorse are clearly impossible to use. Making this generation more selective in choosing products. In accordance with the subjectivity. 
Table 3: Test-t (Men).

\begin{tabular}{|c|c|c|c|c|}
\hline \multirow{2}{*}{ Model } & \multicolumn{2}{|c|}{$\begin{array}{c}\text { Unstandardized } \\
\text { Coefficients }\end{array}$} & \multirow{2}{*}{$\mathrm{t}$} & \multirow{2}{*}{ Sig } \\
\cline { 2 - 3 } & $\mathrm{b}$ & Std. Error & & \\
\hline (Constant) &, 851 & 2,209 &, 385 &, 702 \\
\hline Selebgram &, 670 &, 126 & 5,332 &, 000 \\
\hline
\end{tabular}

The value of t-count $>\mathrm{t}$-table is $5.332>1.6759$ and the significant value for the celebrity is $0.000<$ alpha 0.05 , the coefficient value is 0.670 so the selebgram variable has a positive and significant effect on the buying interest of generation $\mathrm{Z}$ male sex users of Instagram social media thus hypothesis is accepted.

Bussiness posted a photo of a new product on the Instagram application to generate interest in buying users to increase the excitement around the brand. Instagram makes it easier for business people to reach target consumers, it's easier to sell any product, become a facility for online services, get more followers (Landsverk, kjell.H,2014).

Gen $\mathrm{Z}$ is a child born after 1995 - now. This generation lives in the midst of increasingly advanced technological developments and social media that are used today. Gen $\mathrm{Z}$ grows and develops when social media is developing. So, don't be surprised if living Gen $\mathrm{Z}$ has never been separated from social media activities. However, on social media they do not openly show their true identity. They will use pseudonyms for social media profiles. This is done by Gen $\mathrm{Z}$ so that all activities they do on social media are not easily traced by parents.

Gen $\mathrm{Z}$ tends not to believe too much about an ad. Only about less than $25 \%$ of Gen $\mathrm{Z}$ can still receive information or a message on the ad. The rest they are more affected by youtuber or their favorite program on Instagram. Therefore, now many business owners are inviting youtuber or selebgram to promote products.

Based on the results of the above research, it can be concluded that the use of celebrities for products sold on Instagram social media greatly influences its users, especially the $\mathrm{Z}$ generation who are more believing in the celebrities in influencing their buying interest than the male $\mathrm{z}$ generation. man. The celebrity variable consists of several dimensions which include visibility, credibility, attraction and power. Visibility dimension shows that the celebrity who is the endorser of a product is a popular figure on Instagram, the credibility dimension shows that most respondents agree that the endorser can convince the $\mathrm{Z}$ generation to buy products from various product reviews in their Instagram content, the power dimension shows that the program endorsers can improve the image of a product, but the dimension of Attractiveness is generally less attractive to respondents, especially pp (paid promote), which is uploaded as an endorser.

\section{Conclusions}

The results of this study indicate that the positive and significant effect on the buying interest of the $\mathrm{Z}$ generation of Instagram social media users both male and female, which means that the better the influence given by the celebrity as an endorser then the buying interest of the $\mathrm{Z}$ generation will increase and vice versa the lower the influence that is given as an endorser, the interest in buying the $\mathrm{Z}$ generation will decrease.

The $\mathrm{Z}$ generation prefers products / services promoted by selebgrams rather than products / services that do not use celebrities in promoting their products / services. Because the use of 
celebrities is felt to have a level of trust, and is more interesting because Instagram users feel that the product / service they want is also used by a celebrity or celebrity.

\section{References}

Belch, George., Belch, Michael A., 2009. Advertising and Promotion: An Integrated Marketing Communication Perpective, McGraw-Hill. New York, $8^{\text {th }}$ edition.

Erdogan, B.Z., 1999. Celebrity endorsement: A literature review. Journal of Marketing Management. Vol. 14.

Fandos, C., Flavian, C., 2006, Intrinsic and extrinsic quality attributes, loyalty and buying intention: analysis for a PDO product. British food journal. 108(8), 646-662.

Goldsmith, R., Lafferty, B., Newell, S, 2000. The impact of corporate credibility and celebrity credibility on consumer reaction to advertisements and brands. Journal of Advertising, Vol. 29. No.3.

Hughes., G \& fill., Chris., 2006. The Official CIM Course book: Marketing Communication, USA. $1^{\text {st }}$ edition.

Kotler, Philip., Keller, Kevin Lane., 2009. Marketing Management, Pearson Education. New Jersey, $13^{\text {th }}$ edition.

Kotler, Philip., Armstrong, Gary., 2009. Prinsip-Prinsip Pemasaran, Erlangga. Jakarta, $12^{\text {th }}$ edition.

Kotler, Philip., Kartajaya, Hermawan., Setiawan, Iwan., 2016. Marketing 4.0: Moving from Traditional to Digital, Wiley. ISBN: 1119341205,9781119341208.

Landsverk, kjell. H., 2014. The Instagram Handbook: 2014 Edition. PrimeHead Limited. United Kingdom.

Lattimore., Dan., O.Baskin., S.T. Heiman., E. L. Toth., 2009. Public Relations:The Profession and The Practice. McGraw Hill. New York, $3^{\text {rd }}$ edition.

McCarthy, E Jerome., 2009. Pemasaran DasarPendekatan Manajerial, Salemba Empat. Jakarta, $16^{\text {th }}$ edition.

McCracken, G., 1989. Who Is The Celebrity Endorser? Cultural Foundations Of The Endorsement Process. Journal Of Consumer Research. Vol 16. No 3. Pp 310.

Natalia, L., 2008. Analisis Faktor Persepsi yang Mempengaruhi Minat Konsumen untuk Berbelanja. Universitas Gunadarma. Jakarta.

Pratiwi, Andi Lina., 2016. Pengaruh Penggunaan Celebrity Endorser terhadap Minat Beli Pengguna Media Sosial Instagram (Studi pada Mahasiswa Fakultas Dakwah dan Komunikasi). Undergraduate (S1) thesis. Universitas Islam Negeri Alauddin Makassar.

Royan, Frans M., 2004. Marketing Selebrities, PT Elex Media Komputindo. Jakarta.

Shimp, Terrence., 2007. Integrated Marketing Communication in Adverstising and Promotion, Thompson. Ohio, $7^{\text {th }}$ edition.

Sugiarto, Yustinus Sunny., 2012. Pengaruh Celebrity Endorser terhadap Minat Beli Mie Sedaap. Undergraduate (S1) thesis. Universitas Kristen Satya Wacana Salatiga.

Totoatmojo, Kumala Maharani., 2015. The Celebrity Endorser (Selebgram) Effect Toward Purchase Intention On Instagram Social Media. 3rd AASIC: Sustainable Development of Asian Community. Universitas Gadjah Mada. Yogyakarta.

Tyagi, C.L., Kumar, Arun., 2004. Consumer Behaviour, Atlantik Publisher and Distributor, New Delhi.

Wood, Julia T., 2013. Komunikasi Interpersonal Interaksi Keseharian, Salemba Humanika. Jakarta, $6^{\text {th }}$ edition. 